Ann. Biol. anim. Bioch. Biophys., 1978, 18 (2 B), 327-334.

\title{
The meiosis inducing interaction between germ cells and rete cells in the fetal mouse gonad
}

by Anne Grete BYSKOV

The Finsen Laboratory, The Finsen Institute Strandboulevarden 49, 2100 Copenhagen $\emptyset$., Denmark.

\section{Introduction.}

In the mammalian gonad the onset of meiosis of the female germ cells occurs much earlier in life than meiosis of the male germ cells. In the ovary we know that both the differentiation of the somatic components and the initiation of meiosis of the female germ cells depend on influences from the mesonephric connection to the gonad, i.e. the rete system, which secretes a meiosis inducing substance, MIS (Byskov 1974 ; Byskov and Saxen, 1976 ; O and Baker, 1976). In the fetal testis of the mouse and the human, the gonocytes are prevented to enter leptotene stage of meiosis presumably as a result of a meiosis preventing substance MPS secreted by the morphologically sex-differentiated testis (Byskov and Saxen, 1976 ; Luciani et al., 1977).

Observations of preleptotene chromosome condensations of human fetal male germ cells indicate however, that also in the testis a meiosis inducing substance might be secreted, which triggers early stages of meiotic chromosome arrangements in the gonocytes (Luciani et al., 1977).

In the following the behavior of fetal male and female mouse germ cells will be described during the period when meiosis occurs in the ovary. Furthermore, some mechanisms which may control the process of meiosis in the ovary and testis are discussed.

\section{Materials and methods.}

Gonads of fetal mice (Bagg albino) aged 12 1/2, 14 and 17 days post coitus (p.c.) were outdissected and fixed in Zenkers solution. Five fetuses of both sexes from each age were used, i.e. 15 males and 15 females. The gonads were embedded in paraffin serially sectioned at $5 \mu$ and stained with PAS and hematoxylin.

\section{Results.}

On days $121 / 2$ of fetal life the sexes of the gonads are morphologically recognizable. In the testis the germ cells have gathered to form the anlage of the seminiferous 
cords (fig. 1), whereas the oogonia are placed uniformly within the ovary (fig. 2). In both sexes the mesonephric connections to the gonads, i.e. the rete system, are well established. The rete system consists of an extragonadal, a connecting and an intragonadal part. The extragonadal rete is the coiled mesonephric tubules. In the male these tubules will differentiate into vas efferentes, paradidymis and vas aberrans. In the female they become epoophoron and paroophoron. The connecting rete consists of a dense reticulum of coiled cell cords which connect the extragonadal rete tubules and the gonad. The intragonadal rete is cell cords which emerge from the connecting rete and invade the gonad.

In the testis on day $121 / 2$ p.c. the proportion of germ cells to somatic cells is higher within the testicular cords compared to that seen in the ovary. A large number of germ cells in both sexes is in the stage of preleptotene chromosome condensation (fig. 3, fig. 4). The male and female germ cells in these condensation stages are morphologically similar in the histological sections. Most of them are in the late condensation stage (Luciani et al., 1977), with irregular clumps of chromosome condensations lined up close to the nuclear membrane. Degenerating germ cells are seen in both sexes.

In the testis of the 14-day-old fetus almost all germ cells are enclosed in testicular cords (fig. 5). The central part of the cords is dominated by germ cells. Somatic cells are almost exclusively present at the periphery of the cords, lining the basement membrane. The main proportion of the germ cells are in the interphase stage, but some mitotic figures as well as preleptotene condensations are present too (fig. 8). A few germ cells appear to be degenerating (fig. 7).

Some gonocytes are not enclosed within testicular cords but are left isolate outside. The main part of these isolated gonocytes are in their interphase, similar to

\section{PLATE 1}

FIG. 1. - Fetal testis, $121 / 2$ days p. c., in which testicular cords have storfed fo form (arrows). Part of the connecting rete (CR) and an extratesticular rete tubulus $(E R)$ are seen $(\times 250)$.

FIG. 2. - Fetal ovary, $121 / 2$ days p. c. showing the oogonia uniformly distributed within the organ. Parts of the connecting rete $(C R)$ and the extraovarian rete (ER) are shown $(\times 250)$.

FIG. 3. - Resting gonocyfes (G), gonocyfes in mitosis (M) and preleptotene chromosome condensation stages (P. C.) within early testicular cords of a fetus, $121 / 2$ days $p$. c. The proportion of germ cells to somatic cells is higher in the testicular cords than in the ovary (see fig. 4$)$. $(\times 2520)$.

FIG. 4. - Oocytes in preleptotene chromosome condensation stage (PC) in the fetal ovary, $121 / 2$ days p. c. $(\times 2520)$.

FIG. 5. - Fetal testis, 14 days p. c., with well differentiated testicular cords, crowded with gonocytes. Connecting rete (CR) and extratesticular refe (ER) are seen. The marked area is shown in higher magnification in figure $7(\times 250)$.

FIG. 6. - Ovary of a fetus, 17 days p. c. with oocytes in different stages of the meiotic prophase. The connecting rete (CR) is present at the basal part of the ovary $(\times 250)$. 


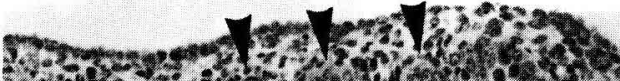

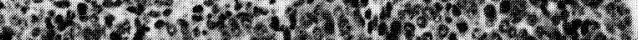

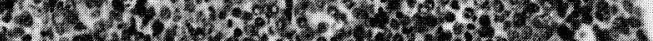

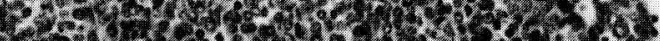

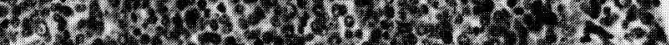

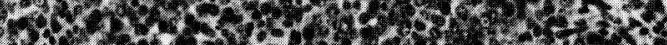

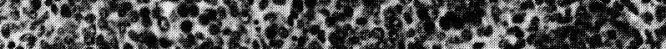

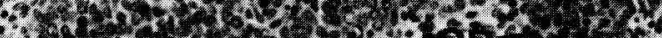

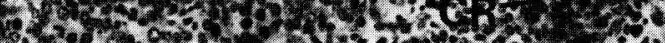

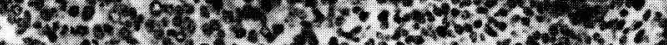

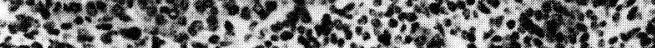

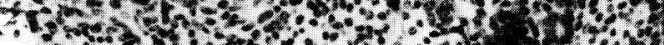

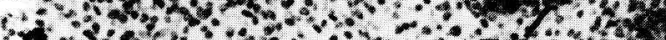

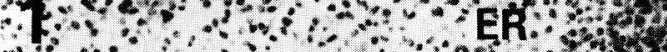

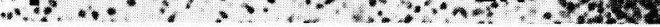

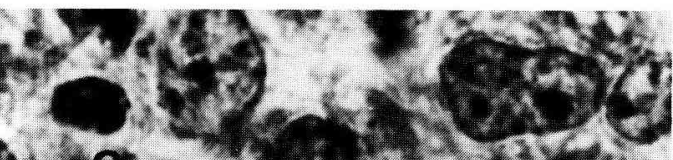
H.

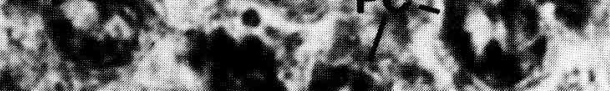

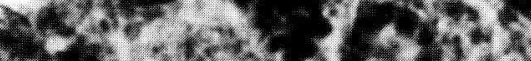

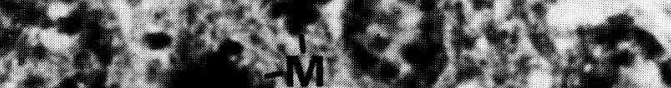

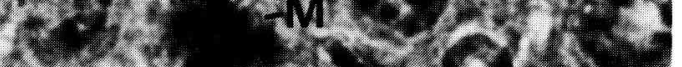

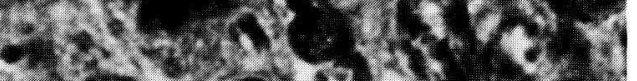

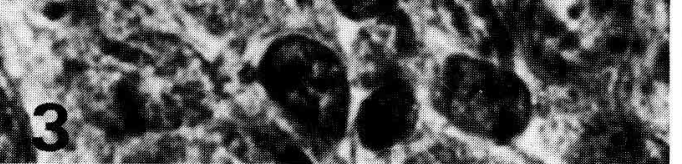

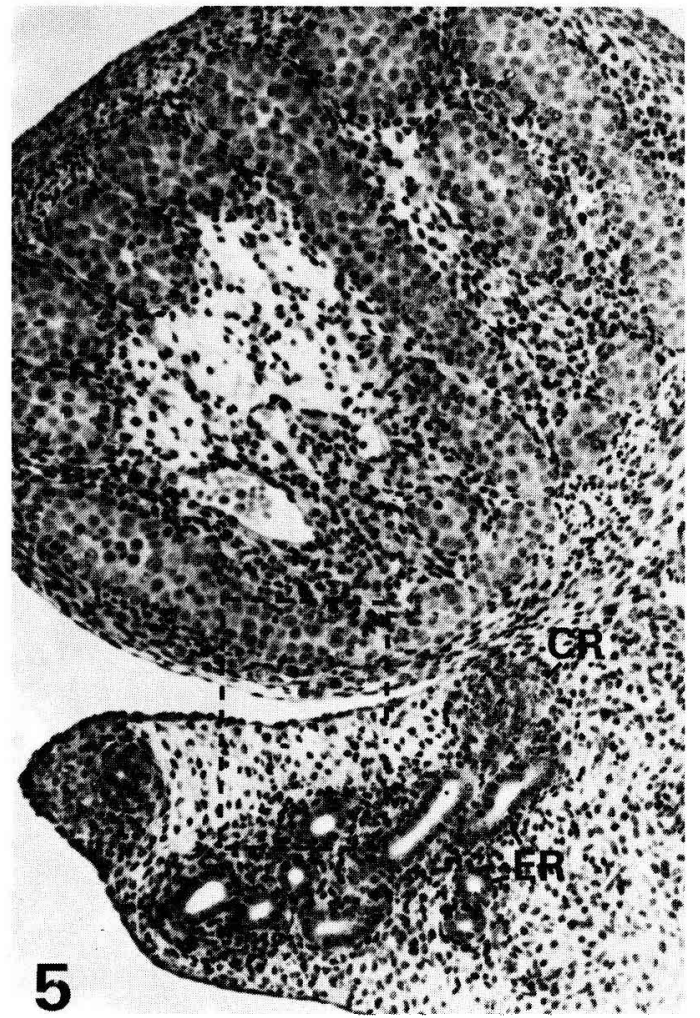

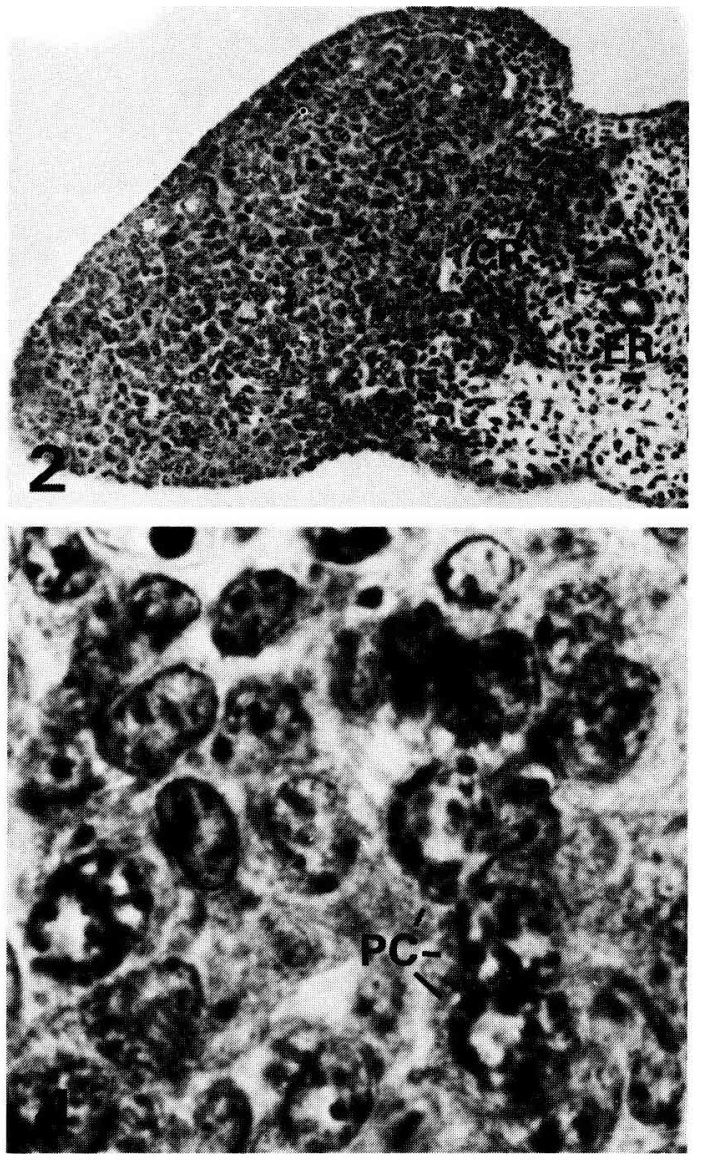


the germ cells enclosed in the testicular cords (fig. 8). However, at two specific areas of the testis the isolated gonocytes enter meiosis : The first area is immediately under the testicular surface, where the extratesticular rete is close to the testis (fig. 5, fig. 7). The second area is within or close to the connecting rete system (fig. 5, fig. 9). Isolated germ cells in the first area had entered leptotene and zygotene stages in the testes of 3 of the 5 fetuses. In the second area close to the connecting rete testis several germ cells in leptotene and zygotene stages were found in all testes of the 5 fetuses (fig. 9).

The germ cells of the 14-day-old fetal ovary are distributed all over the gonad and are in the stages of preleptotene condensation, leptotene and zygotene (fig. 10). The groups of oocytes or single oocytes are separated by numerous somatic cells in contrast to the male germ cells, except the isolated gonocytes. Several oocytes are degenerating with condensed chromatin material (fig. 10).

The morphology of the 17-day-old fetal testis resembles the testis of day 14 p.c. Almost all germ cells are in interphase and only rarely a mitotic figure is seen. Germ cells with pyknotic nuclei are commonly present. Isolated gonocytes outside the testicular cords were confined to areas of the connecting rete and were only found in testes of 2 of the 5 males. These germ cells seemed to be in the stages of degenerating leptotene and zygotene.

In the ovary of the 17-day-old fetal mouse many oocytes are in zygotene and pachytene stages (fig. 6). The oocytes particularly in the center of the ovary have often reached diplotene stage and are well separated from each other by somatic cells. Degenerating oocytes with pyknotic nuclei are frequently seen.

\section{Discussion.}

It is generally stated that the female germ cells enter meiosis at a much earlier time in life than the male germ cells do. However, occasionally meiotic germ cells have been observed in fetal testes, f.i. in the cat (Ohno ef al., 1962) and in grafts of

\section{PLATE II}

FIG. 7. - Higher magnification of the fetal festis, 14 days p. c., shown in figure 5, with a festicular cord filled with gonocytes in interphase. Some gonocytes have pyknotic nuclei $(P)$. Several germ cells are left isolated outside the testicular cords. Some of these are in leptotene stage ( $L$ ). The extratesticular rete (ER) is situated close to this part of the testis $(\times 950)$.

FIG. 8. - Part of a fetal testis, 14 days p. c., situated opposite to areas where the extratesticular refe is close to the festis. Most gonocytes within the testicular cords are in their resting phase (G), but a few are in preleptotene chromosome condensation stage (PC) and in mitosis (M). Gonocytes isolated outside the testicular cords are all in resting stages $(I G)(\times 950)$.

FIG. 9. - Part of the connecting rete of a 14 days old fetal festis con faining fwo germ cells in zygotene stage $(Z)$ and one germ cell, which may be a degenerating inferphase (D) $(\times 2520)$.

FIG. 10. - Fetal ovary, 14 days p. c., with early leptofene $(L)$ and zygofene $(Z)$ stages. Some oocytes are degenerating (D) $(\times 2520)$. 
fetal mouse testes (Ozdzenski, 1972). It has been proposed that germ cells of both sexes at the same time receive stimuli that initiate the onset of meiosis (Ohno ef al. 1962) but that the somatic cells in the developing testis inhibit meiosis to proceed (Tarkowski, 1970 ; Luciani ef al., 1977).

In the fetal and neonatal human testis Luciani ef al. (1977) observed that up to 20 p. 100 of the gonocytes entered the preleptotene chromosome condensation stage. In oocytes of different mammalian species (human : Stahl and Luciani, 1971 ; rabbit : Devictor Vuillet et al., 1973 ; horse : Deanesly, 1975) it is described that this stage preceeds leptotene. As in the human testis a large fraction of the male germ cells in the fetal mouse testis was in the stage of preleptotene condensation at the time when the similar stages were seen in the female germ cells. However, the only germ cells which proceed through the meiotic prophase and enter leptotene and zygotene stages are those placed outside the testicular cords close to the extratesticular rete or the connecting rete tissue.

The fact that not all isolated germ cells outside the testicular cords enter meiosis, but only those placed close to the mesonephrically derived rete system indicates, that a diffusable meiosis inducing substance, MIS, is secreted from the rete cells. MIS reaches only those gonocytes placed close enough to the rete and not enclosed within testicular cords.

It has previously been shown that fetal male germ cells in culture can be triggered to enter meiosis by the action of MIS produced by an older co-cultured rete-containing ovary in which meiosis occurs (Byskov and Saxen, 1976 ; O and Baker, 1976). It was suggested that the rete-system produced MIS since meiosis did not start in rete-depleted fetal mouse ovaries transplanted to a suitable recipient (Byskov, 1974).

The existence of a meiosis preventing substance, MPS, produced by the morphologically sex-differentiated testis, was indicated in a study of co-cultured fetal mouse ovaries and testes, in which the testes inhibited the meiosis of the ovarian germ cells (Byskov and Saxen, 1976). The two substances, the meiosis inducing substance, MIS, and the meiosis preventing substance, MPS, might therefore interact and control the initiation or prevention of the meiotic process. The present observations indicate that MIS is secreted also by the rete system of the fetal mouse testis.

The differentiation of testicular cords is apparantly important in the control of the prevention of meiosis. When the gonocytes move close together and are confined to the testicular cords a specific micromillieu might soon be created. Before this enclosure is finished, the gonocytes are triggered by MIS to enter preleptolene condensation stage. Further influence of MIS, is, however, prevented when the gonocytes are being trapped within the testicular cords. Which mechanisms are responsible for preventing further action of MIS? Is the close packing of the gonocytes sufficient to prevent the action of MIS? Are the sertoli cells induced to prevent meiosis when they are enclosed within the testicular cords fogether with the gonocytes? In this case, the sertoli cells might either produce MPS which is concentrated within the testicular cords and/or create a diffusion-barrier around the germ cells which prevent MIS to reach them. Experimental studies seem to favour the idea, that a MPS is a secreted substance (Byskov and Saxen, 1976). The nature of MPS is unknown, but a similarity to or a functional interaction with androgens or other sex-hormones can not be excluded.

In the ovary the meiotic process also appears to be controlled by MIS and MPS. 
But in contrast to the testis, meiosis is already in progress in oocytes before they are separated from the surroundings and enclosed within their specific micromillieu, the follicles. The results of the isolation of the oocyte within the follicle may be compared to the isolation of the gonocyles within the testicular cords. In both cases isolation from the surroundings affect the process of meiosis : the oocyte is prevented to proceed beyond diplotene stage and the gonocytes are prevented to enter leptotene stage.

Ohno and Smith (1964) suggested that the intimate contact between oocyte and follicle-(granulosa) cells was responsible for maintaining the oocyte in diplotene stage. It is possible that the granulosa cells during early stages of differentiation also produce a MPS as suggested for the sertoli cells. The MPS may either act directly on the oocyte or interact with MIS. That the granulosa cells do produce an inhibitor which prevents oocyle maturation in vitro has previously been demonstrated in pig follicles (Tsafriri and Channing, 1975 ; Tsafriri ef al., 1976).

\section{Conclusion.}

Around the time when the mouse gonads are becoming morphologically sexdifferentiated, the refe system of both sexes seems to secrete a meiosis inducing substance, MIS, which triggers the germ cells to enter preleptotene chromosome condensation stage. In the testis only those gonocytes which are left outside the testicular cords and placed close to or within the rete system will proceed to leptotene and zygotene stages. Gonocytes within the testicular cords are prevented to enter meiosis. It is proposed that a meiosis preventing substance, MPS, is concentrated within the testicular cords, and that the enclosure of gonocytes within cords together with MPS prevent the action of MIS. In the ovary MPS may also be responsible for the arrest of meiosis, when the oocyte is enclosed within the follicle.

$27^{e}$ Congrès international des Sciences physiologiques, Symposium « Germ and somatic cell interaction » Paris, 21-23 juillet 1977.

Acknowledgment. - Is wish to thank Inga Larsen, Annelise Mohr, Poul Riel and Lene Ahrenst for skilful technical assistance.

Résumé. Pendant la période de la différenciation sexuelle des gonades de souris, le système du rete des deux sexes sécrète une substance, le MIS, qui induit dans les cellules germinales l'apparition du stade préleptotène de condensation chromosomique. Dans le testicule, seuls les gonocytes qui ne sont pas enveloppés dans les cordons testiculaires et qui sont placés près du rete débutent la prophase méiotique. Les gonocyles qui sont dans les cordons testiculaires n'entrent pas en prophase méiotique. Il est suggéré qu'une substance empêchant l'entrée en méiose, le MPS, est présente dans les cordons testiculaires et que l'isolement des gonocytes dans les cordons où se trouve le MPS, prévient l'action du MIS.

Dans l'ovaire le MPS pourrait être responsable de l'arrêt de la méiose, quand l'ovocyte est inclus dans le follicule. 


\section{References}

BYSKOV A. G., 1974. Does the rete ovarii act as a trigger for the onset of meiosis ? Nature, 252, 396-397.

BYSKOV A. G., SAXEN L., 1976. Induction of meiosis in fetal mouse testis in vitro. Develop. Biol., 52, 193-200.

DEANESLY R., 1975. Germ cell development and the meiotic prophase in the fetal horse ovary. J. Reprod. Fert. Suppl., 23, 547-552.

DEVICTOR-VUILLET M., LUCIANI J. M., STAHL A., 1973. Individualisation d'un stade préleptotène de condensation chromosomique dans l'ovocyte de la lapine. C. R. Acad. Sci., Paris sér. D, 276, 2453-2456.

LUCIANI J. M., DEVICTOR M., STAHL A., 1977. Preleptotene chromosome condensation stage in human fotal and neonatal testes. J. Embryol. exp. Morph., 38, 175-186.

O W., BAKER T. G., 1976. Initiation and control of meiosis in hamster gonads in vitro. J. Reprod. Fert., 48, 399-401.

OHNO S., SMITH J. B., 1964. Role of fetal follicular cells in meiosis of mammalian oocytes. Cytogenetics, 3, 324-333.

OHNO S., STENIUS C., WEILLER C. P., TRUJILLO J. M., KAPLAN W. D., KINOSITA R., 1962. Early meiosis of male germ cells in fefal testis of Felis Domestica. Exp. Cell Res., 27, 401-404.

OZDZENSKI W., 1972. Differentiation of the genital ridges of mouse embryos in the kidney of adult mice. Arch. Anat. micr., 61, 267-278.

STAHL A., LUCIANI J. M., 1971. Individualisation d'un stade préleptotène de condensation chromosomique au début de la méiose de l'ovocyte foetal humain. C. R. Acad. Sci., Paris sér. D, 272, 2041-2044.

TARKOWSKI A. K., 1970. Are the genetic factors controlling sexual differentiation of somatic and germinal tissues of a mammalian gonad stable or labil ? In Fogarty int. Cent. Proc. No. 2, 49-60. Environmental influences on genefic expression. Biological and behavioral aspects of sexual differentiation. U. S. Gov. Print. Off.

TSAFRIRI A., CHANNING C. P., 1975. Influence of follicular maturation and culture conditions on the meiosis of pig oocytes in vitro. J. Reprod. Fert., 43, 149-152.

TSAFRIRI A., POMERANTZ S. H., CHANNING C. P., 1976. Inhibition of oocyte maturation by porcine follicular fluid : partial characterization of the inhibitor. Biol. Reprod., 14, 511-516. 